DOI https://doi.org/10.30525/978-9934-588-91-4-5

\title{
АНТРОПОЛОГІЧНИЙ ХАРАКТЕР В КОНТЕКСТІ ПРАВОСЛАВНОЇ РЕЛІГІЇ
}

\author{
Сало Г. В. \\ кандидат філософських наук, \\ методист Науково-методичного иентру досліджень, \\ наукових проектів та програм \\ Київського університету імені Бориса Грінченка \\ м. Київ, Украӥна
}

На сьогодні знання про людину досліджено на теоретичному та емпіричному рівні, але кожного разу ми аналізуємо людину 3 іншого боку і відбувається перетворення філософської думки. Розглядаючи буття людини постає проблема в іiі пізнанні. У концепціях антропологічного характеру релігійного спрямування переважає ідея боголюдяності, яка розкриває істинну людяність через відшукання у собі божественного, богоподібного. Боголюдяність виявляється у святості, абсолютній цінності і недоторканості людського життя. Християнська заповідь «Не вбий!» націлена на сакральне освячення кожного життя. У цьому контексті можна пригадати заклик Іоана Павла II: «Шануй, бережи, люби життя і слугуй життю! Тільки на цьому шляху знайдеш справедливість, розвиток й істинну свободу, спокій, щастя» [1, с. 9].

Людина як особистість, будучи боголюдяною істотою, відкриває перед собою нові горизонти для духовного зростання. На цьому шляху справа спокути освячує, перетворює людину, утверджує іiі у повноті буття. Отже, феномен спокути наповнює концепцію антропологічного характеру новими ідеями. У християнській традиції проблема спокути корелюється з розумінням жертви Ісуса Христа (сина Божого), в якій засвідчується принцип людинолюбства Бога - Отця. Людина, маючи природну схильність до зла, отримує можливість відновити повноту власного буття. Завдяки жертві Ісуса Христа здійснюється звільнення людства. Причому подолання ним смерті вселяє надію на перемогу добра у світі.

Щодо акту спокути, то це є допомога людині, здійснена Ісусом Христом. Розп'яття Христа є свідченням солідарності Бога 3 людиною, яка страждає. Бог стає на бік людини і стає радикально. Людина постійно переживає стан напруги між тим, ким вона $\epsilon$, i тим, чим повинна бути. Моральний обов'язок, який стоїть перед кожною особистістю, свідчить про те, що хоча природа людини схильна до зла, але в ній міститься божественне начало. 
Загалом, у різних релігійних традиціях (наприклад, християнство, мусульманство, іудаїзм) вивчення релігії як такої пов'язане з ії розумінням у межах конкретного віросповідання. У світлі такого підходу «фільтруються» всі інші релігійні традиції. Для богословів характерне несприйняття альтернативних розумінь релігійних явищ, навіть якщо вони розкриваються в межах одного віросповідання. Будь-яке богослов'я $\epsilon$ розмірковуванням над змістом релігійного досвіду. Основною його метою $є$ поглиблення і пояснення різноманітних стосунків між Богом і людиною. Звідси випливає пояснення основоположень певного конфесійного віровчення. Для богословського дослідження характерним $є$ нормативний підхід до релігії, тобто воно орієнтоване на доказ істинності своєї релігії і ці положення власної релігії сприймаються як норма, даність.

\section{Література:}

1. Йоан Павло II. Енцикліка Evangelium vitae до єпископів, священників і дияконів, ченців, черниць, світських католиків та до всіх людей доброї волі про вартість і недоторканість людського життя. Ватикан : Libera Editric e Vaticana, 1995. C. 9. 